\title{
BOD Pressure in the sustainability of the Citarum River
}

\author{
Resha Ayu Putri Belinawati ${ }^{1}$, Tri Edhi Budhi Soesilo ${ }^{1}$, Herdis Herdiansyah ${ }^{1 *}$, and Intan \\ Nurul Aini ${ }^{1}$ \\ ${ }^{1}$ School of Environmental Science, Universitas Indonesia, Salemba, Indonesia
}

\begin{abstract}
As one of the 10 most polluted rivers in the world, Citarum river pollution has become the world's spotlight. The pollution that occurred along the Citarum River in West Java has been the concern of the local government. Pollution not only comes from a plant and household, but also from industries. In this study the authors use descriptive quantitative method, where researchers will describe and compare the existing variables to see the possibilities that arise. Variable used is the number of industries that exist and how the impact against BOD. Biochemical Oxygen Demand (BOD) is a measuring instrument that is widely used to see the quality of oxygen levels in the water. In this paper shows that there is a possibility if BOD increases if the number of industries increases.
\end{abstract}

\section{Introduction}

Citarum is the longest river in West Java has quite a lot of functions for the people around, especially the people around the watershed. Most of them using Citarum river for daily using, Eg. Drinking, irrigation for farmers. There is 56\% of the Upper Citarum Watershed belongs to the administrative district of Bandung, West Java Province [1]. Citarum River is one of Indonesia's strategic rivers, from which the three multi-purpose dam [2].

By the time, the development along the River Ciliwung increasing. The increasing number of residents impacted a large number of settlements and also the industry along the Citarum River. However, after the construction of a large number of factories along Citarum River, Citarum River is no longer a source of water for residents along the Citarum watershed. No less than 1,500 plants located upstream freely discharge waste to creeks or Citarum River, making the Citarum River Basin more polluted [3]. Waste discharged into the Citarum River in liquid or solid form, has exceeded the capacity possessed by the Citarum River. "The concentration of $\mathrm{BOD}_{5}$ which is a pollution indicator shows that almost all observation stations have BOD concentrations that exceed the class III water quality standard $(>6 \mathrm{mg} / \mathrm{L})$, BOD pollution load from some of the highest observed Citarum River from Ciwideuy River and the smallest is from Cisangri River [4].

There are still many industries that dispose of waste into factors supporting the high level of BOD along the Citarum watershed. The effect of industrial waste water on the water quality in Citarum River is seen from the increase of organic matter content (BOD)

* Corresponding author: herdis@ui.ac.id 
and the decrease of dissolved oxygen (DO) from upstream to downstream after passing industrial zone [5]. Near the textile industry area, the value of Biochemical Oxygen Demand (BOD) and Chemical Oxygen Demand (COD) exceeds the standard for all classes of water, at reference point, BOD ranges from $1.7 \mathrm{mg} / \mathrm{L}$, while in downstream river BOD values reach $9.36 \mathrm{mg} / \mathrm{L}$ to $523.00 \mathrm{mg} / \mathrm{L}[6]$. Without treatment. The Citarum River is located in western part of Java, and its basin covers $5960 \mathrm{~km}^{2}$, the total length of the main river is about $315 \mathrm{~km}$ and flows from its water sources in mount Wayang to the Java sea in the north [7]. The designation of the Citarum River is divided by region. Upper watershed is still dominated with natural forest, tea, and for the middle water shed is dominated Village, Vegetable Garden, Paddy Field, and the lower watershed is dominated with industries [8].

The Government of Indonesia in 2015-2019 have National Medium Term Development Plan/Rencana Pembangunan Jangka Menengah Nasional called RPJMN. The plan states that the 2015-2019 RPJMN targets to achieve universal access or 100\% access coverage for drinking water and sanitation to secure drinking water. Citarum Bestari (Bersih, Sehat, Indah, dan Lestari) is a program created by West Java Provincial Government in solving the Citarum River pollution problem, at: Governor Regulation No. 78 Year 2015 About Citarum Bestari. This program is a priority program for West Java Provincial Government and it is expected that this program can restore the function of river basin Citarum as before.

In this study the authors want to see how the industry can increase the load of BOD, and how the role of government in handling these problems, as the result of this research we will know how far the role of government in the supervision of toxic waste disposal seen from the load of BOD found.

The return of watershed functions is also supported by the agreement of countries that have participated in the signing of SDGs (Sustainable Development Goals). SDGs has 17 Goals, these goals support to meet the overall objectives of SDGs. SDGs has a time period of up to 2030 where each country must reach before the year is reached. The purpose of SDGs No. 6, specifically discusses water and sanitation. The big goals from SDGs 6 Water and sanitation is "ensuring that communities have access to clean water". One of these indicator from the goals is to reduce pollution and reduce the amount of waste disposed into the river. Biochemical Oxygen Demand (BOD) is a measuring instrument that is widely used to see the quality of oxygen levels in the water. BOD parameters are generally used to determine the level of waste water pollution. BOD determination is essential to trace pollution flow from upstream to estuary [9]. BOD checks are needed to determine pollution loads from waste water and to design a biological treatment system [10]. The aerobic bacteria consume and oxidise the organic matter; the BOD test analyzes how much oxygen is being consumed [11].

Biological oxygen demand is defined as the amount of oxygen required by organisms at the breakdown of organic matter, under aerobic conditions, breakdown of organic matter means that this organic material is used by the organism as a foodstuff and its energy is obtained from the oxidation process [12]. Biochemical oxygen demand (BOD) is one frequently used tools for measure the level of pollution in the water. Indonesia has regulations relating to waste water pollution which are regulated in: Government Regulation No. 82 of 2001 on Water Quality Management and Water Pollution Control. The legislation explains that BOD has 4 classes, a range of contaminants are present in the river, from both industrial and domestic sources [13]. Industrial waste is a waste generated by the industry resulting from the results of the industrial activity. Household waste is waste that comes from household activities such as plastic waste, wet garbage, detergent foam and others. both of these wastes can be indicated to increase the BOD load we find along the Citarum River, that can reduce the quality of the Citarum River. 


\section{Material and method}

\subsection{Quantitative Descriptive}

In this study the authors use descriptive qualitative methods to know how the number of industry can impact on BOD level in the river Citarum. This descriptive approach explains using existing data, and in pour in narrative form. Quantitative descriptive often undertaken with the intention of relating the findings to other work in the field [14]. In this study the authors want to compare the findings that have been there before with the current situation. Quantitative descriptive thus lead logically from an exploratory, hypothesis generating phase to analytical confirmatory hipotesis testing phase [15].

\subsection{Sustainability}

This principle of sustainability is fundamental to running SDGs as well as development. Sustainability is the most widely used buzzwords of the past two decades, there is nothing, it seems, that cannot be described as 'sustainable': apparently everything can be either hyphenated or paired with it [16]. Sustainability is the ability of earth and human nature to survive, evolve, and adapt to changes in environmental conditions over a long period of time [17]. In general, sustainability is focused on increasing the quality of life with respect to environmental, social and economic considerations, both in the present and for future generations [18]. Sustainability is the ability of a natural, human or mixed system to withstand or adapt to, over an indefinite time scale, endogenous or exogenous changes perceived as threatening [19].

\section{Results and discussion}

\subsection{Result}

The simulation is done to predict the BOD load with the amount of industry produced during the production process, The figure illustrates that there is a possibility if the number of industries increases then the number of BOD increases. If the table shows that the number of BOD is not influenced by the number of industries. Industry positions do not have a major impact on the high BOD. It can be said the increase in the number of BOD is different in each industry and can be increased every day. Increasing industrial activity may indicate an increase in the number of BOD available. The higher the number of industries, the greater the BOD load. With the increase in the number of BOD indicates that the improvement of human quality in the principle of sustainability has not been fully implemented. The side of the environment in this case is still in the absence of it is proved still high number of BOD. 
Table 1. Debit Simulation and Actual Concentration of Industry [20].

\begin{tabular}{|c|c|}
\hline Number of Industries & BOD Load $(\mathbf{k g} / \mathbf{h r})$ \\
\hline 20 & 78.4 \\
\hline 20 & 147 \\
\hline 30 & 325.5 \\
\hline 30 & 430.5 \\
\hline 30 & 491.4 \\
\hline 30 & 540 \\
\hline 30 & 630 \\
\hline 30 & 720 \\
\hline 30 & 810 \\
\hline 29 & 870 \\
\hline
\end{tabular}

\subsection{Discussion}

This Citarum River problem encompasses many aspects, not only environmental problems affected, but also social and economic problems. Economically fishing communities in particular lost their livelihood, because the fish they get is already getting lost due to waste issued by the factory. Socially the previous River Citarum has a social function, one of which is social interaction. This citarum river problem can be said quite complex, because the impact is quite a lot.

Water is the most dominant element on earth. $71 \%$ of the earth's surface is covered by water in the liquid form of the ocean and ocean, and in the solid form of ice in the Arctic (Arctic) and Antarctic (south pole)[21]. In everyday life humans are also not separated from to meet their daily needs, such as eating, drinking, washing and others. Therefore, it is of utmost importance to maintain the sustainability of water resources, so that these resources can be utilized by humans and others, now and also in the future [22]. The world is currently faced with SDGs (Sustainable Development Program). The principle of "no one left behind" [23] is of concern to developed and developed countries. Implementation of SDGs in Indonesia depends on supporting policy. The Indonesian government has a policy that supports the objectives of the SDGs, which are called RPJMN. RPJMN is applied to programs owned by the local government of West Java, to meet the goal no 6 one of them.. The West Java Provincial Government created a program to support that goals, namely Citarum Bestari. Citarum Bestari has a goal that is not much different from the destination SDGs are, to reduce the waste of waste discharged into the river. The implementation of the program, is conducted coordination and consultation between stakeholders, prioritizes community, planning, and implementation [24].

Based on the above results, it can be seen that the relationship between the number of industries with a BOD load of 55\%. There is a possible correlation between the numbers of industries with the BOD load. The BOD load can increase as the number of factories increases. The problems that arise between factories and society are quite large in number. For examples: Citarum River passes Karawang area, which was formerly referred to as rice granaries because there are still many rice plants planted there. Over time Karawang is no longer a rice granary but instead has turned into an industrial center. Construction of the factory began to bloom massively. The construction of factories alongside the river has a good objective, one of which is to absorb labor. Yet it is unfortunate that the disposal of industrial waste is not in accordance with the procedure. Factory waste that is directly disposed of the river will have a lot of impact for the people living in the proximity. 
Especially for the fishermen and farmers who are still dependent on the Citarum River. The contaminated water will affect the fish population, and the irrigation of rice fields that use Citarum river water, which in turn will affect the quality of the rice.

The impact that comes from waste pollution is quite a lot. Like: Increasing the amount of waste, In 2016 BBWS Citarum mentions that household waste disposal reaches $60 \%$, liquid chemical industry waste disposal reaches $30 \%$, and $10 \%$ for agricultural and livestock waste disposal, total waste in the upper reaches of the Citarum River, around Bandung Regency has reached $500.000 \mathrm{~m}^{3} /$ year [25]. In addition, water deficit also threatens Jakarta and Bandung. Drinking water deficit for Bandung Raya area. This happens because the forest's ability to absorb rainwater drops dramatically because of deforestation / deforestation. If this continues to happen then the future of future generations can be said to be worrying.

Citarum Bestari that has been made from 2015 is expected to reduce waste disposal to the Citarum River but to date there is still pollution. The waste found along the river citarum is not only industrial waste that is not visible directly, and also household waste is still found along the river Citarum. The role of government in formulating policy and policy implementation is very important but it needs considerable supervision aspect. In addition, there needs to be social intervention involving the community in river management [25]. For example the community engagement approach undertaken along rivers, especially in urban areas can help maintain river sustainability [26]. Now the issue of community participation in maintaining the environment has been widely applied in various environmental issues.

\section{Conclusion}

The high number of industries along the Citarum Section, proves that economic development is increasing, evidenced by the shifting of functions that used to be rice fields turned into industrial plants. Numbers of industries along the Citarum River can increase the load of BOD. The results showed there was a correlation or influence between the numbers of industries with the high load BOD on the Citarum watershed, with the correlation coefficient of 0.557 . The result is, the load of BOD will increase if the supervision aspect of the industry is still minimal. Basically increasing the BOD load is not influenced by the amount of industry or even influenced.

Supervision aspect is needed, because in fact the increase in the BOD load is not only based on the number of industries but also household waste. Polution along Citarum River, show that the Increasing the load of BOD is influenced from the lack of supervision in the implementation. Supervision and execution are of particular importance in terms of a policy. Cooperation between sectors is a good collaboration in the supervision of a policy because basically to make the Citarum River Bestari, required cooperation between sectors. Good supervision management will improve the quality of the better Citarum river.

\section{Acknowledgements}

This research is funded by the Grant of Indexed International Publication for Final Project of Students/Publikasi Terindeks Internasional Untuk Tugas Akhir Mahasiswa (PITTA) Universitas Indonesia 2018 with contract number 2579/UN.R3.1/HKP.05.00/2018 


\section{Reference}

1. A. Mufubi, Y. Setiawan, H. Effendi. Land use/land cover change detection in an urban watershed: a case study of upper Citarum watershed, West Java Province, Indonesia. Procedia Environmental Sciences 33, (2016).

2. Suharyanto, J. Matsushita. Integrated basin-based wastewater management system or water pollution control in an enclosed waterbody of the upper Citarum River Basin, Indonesia: Case study of Saguling Reservoir. Lakes \& Reservoirs, Research and Management 16, (2011).

3. A. Prijono. Mastaka Citarum. Jawa Barat: Balai Besar Konservasi Sumber Daya Alam Jawa Barat (Central Conservation of Natural Resources West Java). (2015)

4. BPPKSI. Marine and Fisheries Ministry. Retrieved from http://bp2ksi.litbang.kkp.go.id/index.php/8-halaman-depan/50-penelitian-teknologipengendalian-pencemaran-dan-modeling-kualitas-air-di-das-citarum-jawa-barat

5. N.T. Bukit, I.A. Yusuf. Beban pencemaran limbah industri dan status kualitas air Sungai Citarum. Jurnal Teknologi Lingkungan 3, 2 (2002)

6. Sunardi, D. Sumiarsa. Bahan beracun lepas kendali. Greenpeace and Walhi (2012).

7. Nana Terangna Bukit. Water quality conservation for the Citarum River in West Java. Water Science and Technology 31, 9 (1995)

8. Sunardi. Distribution of Fish in the upper Citarum River: an adaptive response to physico-chemical properties. HAYATI Journal of Biosciences 19, 4 (2012)

9. Salmin. Oksigen terlarut (DO) dan kebutuhan oksigen biologi (BOD) sebagai salah satu indikator untuk menentukan kualitas perairan. Oseana XXX, 3 (2005).

10. G, Alaerts, S.S. Santika. Metoda Penelitian Air (Water Research Methods) (Usaha Nasional, Surabaya, 1987)

11. A. Berlemann. Using a water quality index to determine and compare creek water quality. American Water Works Association 105, (2013)

12. PESCOD, M. D. A.I.T. Bangkok (1973).

13. Green Croos and Black Smith Institute. Citarum River, Indonesia. (2013)

14. P. Huxley. 'Quantitative-Descriptive' Articles in the British Journal of Social Work, Volumes 1-14. The British Journal of Social Work 18, 2 (1988)

15. H.J.B. Birks. Recent methodological developments in quantitative descriptive biogeography. Finnish Zoological and Botanical Publishing Board Stable 24, (1987)

16. I. Scoones. Sustainability. Development in Practice 17, (2007)

17. G.T. Miller, S. Spoolman. Environmental Science (Cengage Learning, Boston, 2014)

18. E.R.D. Marchese. Science of The Total Environnent 613-614 (2017)

19. S.R. Dovers. Sustainability: demands on policy (Cambridge University Press, 1996)

20. Director General of Pollution Control and Environmental Degradation. Citarum River Pollution Load Allocation. Jakarta: Director General of Pollution Control and Environmental Degradation) (2014).

21. M.F. Imansyah. Studi umum permasalahan dan solusi das citarum serta analisis kebijakan pemerintah. Jurnal Sosioteknologi 11, 25 (2012)

22. I. Juwana, N. Muttil, B.J.C. Perera. Uncertainty and sensitivity analysis of West Java Water Sustainability Index - A case study on Citarum catchment in Indonesia. Ecological Indicators 61, (2016)

23. D. Satterhwaitte. A new urban agenda? Environment and Urbanization 18, (2016) 
24. CitaCitarum. Tentang Citarum (About Citarum). http://citarum.org/tentangkami/tentang-cita-citarum.html

25. D. Asteria, H. Herdiansyah, I.W.A. Apriana. Women's environmental literacy as social capital in environmental management for environmental security of urban area. Conference Series: Earth Environmental Science 30 012014, (2016)

26. A. Brotosusilo, D. Utari, A.A. Satria. Sustainability of water resources in the upstream watershed-based community engagement and multistakeholder cooperation. IOP Conference Series: Earth Environmental Science 30 012018, (2016) 